\title{
The State of Entrepreneurship Education in Universities in Shanghai, China: A Survey from Students’ Perspective
}

\author{
Yiyang Fan*, Xing Zhang, Yuting Qiu \\ Business School, University of Shanghai for Science and Technology, Shanghai, China \\ Email: *fyyqq@usst.edu.cn
}

Received November $13^{\text {th }}$, 2012; revised December $14^{\text {th }}$, 2012; accepted December $29^{\text {th }}$, 2012

\begin{abstract}
In order to understand the status quo of entrepreneurship education in universities in Shanghai, this article draws data from a survey on college students in Shanghai. The sample covers a wide range of students from different majors, school years, and regional backgrounds. The analysis focuses on their recognition of entrepreneurship education, the curriculum, and the preparation of entrepreneurship, etc. Based on the survey data, the article also discusses the current problems of entrepreneurship education in universities and provides suggestion in terms of the conception of reforming entrepreneurship education, the entrepreneurship curriculum, and the mechanism supporting entrepreneurship among college students.
\end{abstract}

Keywords: Student Surveys; Entrepreneurship Education; Universities in Shanghai

\section{Introduction}

Entering into the implementation phase of the 12th Five-year Plan, entrepreneurship education has been carried out pervasively in Chinese universities. According to regional economic environment and industry characteristics, many colleges and universities actively explore the entrepreneurship education model for training innovation personnel which combined with the school's professional characteristics and educational resources.

Shanghai creates an active environment for entrepreneurship. Many government agencies and non-profit organizations, such as Shanghai Municipal Education Commission, Shanghai Municipal Labor and Social Security Bureau, and Shanghai Technology Entrepreneurship Foundation for Graduates, provide entrepreneurial knowledge, entrepreneurial skills training, entrepreneurial guidance and venture capital support for the college students' entrepreneurial practice to realize their business dreams.

With the characteristics of openness and comprehensive, entrepreneurship education is difficult to follow a fixed pattern. Moreover, colleges and universities are shackled by a long-term and inherent professional education model and will encounter new issues and problems in implementing the reform of innovative entrepreneurship education. Therefore, it's necessary to combine different professional education and education resource configuration, meet with the needs of the educatee, innovate the teaching form and teaching management style, and seek a pragmatic approach to carry out entrepreneurship education.

\section{Background and Methodology}

\section{Respondents}

To fully understand the state of entrepreneurship education in

*Corresponding author.
Chinese universities and to ensure a highly representative result, a survey was administered to 700 students at seven colleges and universities in Shanghai. The respondents consist of undergraduates, postgraduates and doctoral candidates who majored in science, technology, engineering, mathematics (STEM), economics, management, arts, humanities, and so on. The profile of the filtered data set is shown in Table 1.

To avoid repeated counting, the total number of "Region" and "City/country" are smaller than that of respondents respectively.

\section{Questionnaire Contents}

In accordance with the purpose of the research, the questionnaire is mainly consisted of four modules to measure students' perceptions and personal opinions towards entrepreneurship education, entrepreneurial values and entrepreneurial

Table 1.

The profile of respondents.

\begin{tabular}{clccc}
\hline Category & Characteristic & Number & Ratio & Total \\
\hline \multirow{2}{*}{ Gender } & Male & 317 & $49.92 \%$ & \\
& Female & 318 & $50.08 \%$ & 635 \\
& Freshman, Sophomore & 215 & $33.86 \%$ & \\
Grade & Junior, Senior & 232 & $36.54 \%$ & 635 \\
& Graduate, Doctor & 188 & $29.6 \%$ & \\
& STEM & 205 & $32.28 \%$ & \\
\multirow{5}{*}{ Major } & Economics, management & 204 & $32.13 \%$ & 635 \\
& Arts, humanities & 226 & $35.59 \%$ & \\
& The Central & 132 & $32.27 \%$ & \\
& The East & 192 & $46.94 \%$ & 409 \\
& The West & 85 & $20.78 \%$ & \\
& Villages, township & 134 & $27.46 \%$ & \\
& Prefectural-level city, county & 117 & $23.96 \%$ & 488 \\
& Provincial capital, municipality & 237 & $48.57 \%$ & \\
\cline { 2 - 5 } & & & &
\end{tabular}


preparation, along with respondents' demographic information and practical experience. As shown in Figure $\mathbf{1}$ below.

\section{Valid Questionnaires and Data Processing}

The questionnaires were distributed 700 copies, and 659 were returned. Excluding invalid surveys of 24, there are a total of 635 valid surveys for a valid response rate of about $90.7 \%$. After filtering the surveys, we use SPSS16.0 statistical software for analysis and data processing.

The reliability of the questionnaire was tested before processing. But with limitations of the time and difficulties, this article only tested the internal reliability of the questionnairethe internal consistency and split-half reliability, regardless of the test-retest reliability. The test shows that the Cronbach's reliability coefficient for this scale is 0.913 , indicating good internal consistency of the questionnaire. At the same time, all odd-and even-numbered questions in this questionnaire are divided into odd array and even array with a split-half reliability of 0.869 , also demonstrating good reliability.

\section{Perception of Entrepreneurship Education}

\section{Basic Situation of Students' Opinions towards Entrepreneurship Education}

To understand students' demand and develop the entrepreneurship education effectively, the survey inquired the respondents' opinions towards entrepreneurial curriculum, such as whether entrepreneurship education is necessary even if he/she has no entrepreneurial intention, whether he/she has ever attended entrepreneurship as elective courses, and whether the entrepreneurial courses will influence their entrepreneurial ideas.

The survey data show that $71 \%$ of students think that the entrepreneurship curriculum is necessary even if there is no entrepreneurial plan. This result indicates that students have strong demand for entrepreneurial courses, as well as high level of acceptance.

With respect to the implementation of entrepreneurship education, $52 \%$ of respondents said that they had ever minored in entrepreneurship. This data show that entrepreneurship education enjoys a high degree of popularity. Furthermore, many colleges and universities have gradually emphasized on the development of entrepreneurial curriculum, and offered entrepreneurial course as required course.

330 students in this survey have ever attended entrepreneurrial curriculum, of whom $21.5 \%$ believe that the entrepreneurial curriculum have a significant effect, $51.5 \%$ think a certain ef-

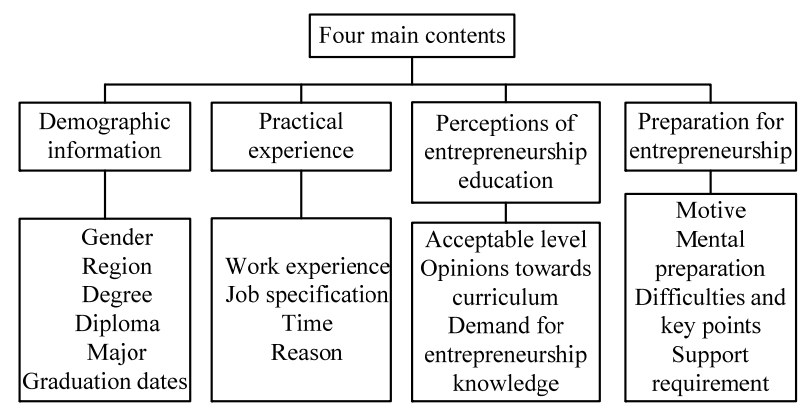

Figure 1.

Four main contents of questionnaire. fect, while $27 \%$ say no effect. To a certain extent, these results indicate that the existing entrepreneurial courses have received wide acceptance, though challenges remain for the ongoing entrepreneurship education and curriculum system.

Besides, in reply to "whether he/she has an entrepreneurial plan”, $46 \%$ of students expressed their intention to start a business. The enthusiasm for entrepreneurship and the demand for entrepreneurship education both promote the development of entrepreneurship education in shanghai.

\section{Differential Analysis of Entrepreneurial Curriculum Evaluation}

To study the different demand for entrepreneurship education, this survey makes gender, grade, major, and origin as basic variables to explore the diversified needs. This paper uses cross analysis, Scheffe and LSD comparison for data processing with SPSS16.0.

The results show that, $66.2 \%$ of the students who think highly of entrepreneurial curriculum are males. Apparently, males hold a higher regard for entrepreneurial curriculum than females.

The students' attitude towards the effect of entrepreneurial curriculum varies with different majors and grades. Of the students who think highly of entrepreneurial courses, $39.4 \%$ are in STEM majors, $32.4 \%$ in arts and humanities majors, while $28.3 \%$ in economics and management majors. Of the students who think entrepreneurial courses have modest effect, 38.8\% are in STEM majors, $25.9 \%$ in economics and management majors, while $35.3 \%$ in arts and humanities majors. Of the students who think entrepreneurial courses have little effect, $28.1 \%$ are in economics, management and STEM majors, while 43.8\% in arts and humanities majors.

\section{Curriculum Evaluation of Entrepreneurship Education by Students in Different Majors}

Students in different majors hold different opinions towards entrepreneurial curriculum. Students in economics and management majors have learned much more knowledge of business operation and management in their specialized courses. But students in STEM majors have little access to such professional knowledge, therefore, they have an intense interest in entrepreneurial management knowledge, as well as much more demand for transforming the professional technology into business value (Postigo \& Tamborini, 2005). This is one of the reasons that students in STEM majors think much highly of the effect of entrepreneurial curriculum.

\section{Curriculum Evaluation of Entrepreneurship Education by Students in Different Grades}

Students in different grades also hold different opinions towards entrepreneurial curriculum. $46.5 \%$ of the students who think highly of entrepreneurial curriculum are postgraduates and doctoral candidates, while $19.7 \%$ are junior and senior college students. And only 15.6 of all the freshmen and sophomores think highly of the effect of entrepreneurial curriculum. Of the students who think entrepreneurial courses have little effect, $56.2 \%$ are freshmen and sophomores, while only $11.2 \%$ postgraduates and doctoral candidates. The details of variance analysis are shown in Table 2. 
Due to the respondents' personal experiences, expertise and future career planning, the respondents' degree of concern and the demand for the entrepreneurial courses is different. All in all, among the students who think highly of entrepreneurial curriculum, students in higher grades are more than that in lower grades, males are more than females, postgraduates are more than undergraduates, and students in STEM majors are more than in economics, management, arts and humanities majors.

\section{Entrepreneurial Curriculum Design and Demand Analysis}

\section{Curricular Design and Demand Analysis}

In order to understand students' demand for entrepreneurship education, such as curricular design, the forms and contents of education activities, the survey inquired respondents through some ranking questions such as the effective entrepreneurial curriculum, the most interested entrepreneurial knowledge, the important qualities that teachers should possess in entrepreneurship education and so on. The results are shown in Table 3.

According to the survey data, students think that the most effective entrepreneurial curriculums are entrepreneurship internship and entrepreneurial management course. Entrepreneurial course which involved in professional curriculum and short-term internship course rank the third and fourth, but public elective courses and career guidance rank the last two. This indicates that students pay more attention to entrepreneurial management and the experience of entrepreneurship internship, need more opportunities for entrepreneurial practice and attend the professional entrepreneurial management courses. The general courses for entrepreneurship and career guidance can no longer meet the students' demand for entrepreneurship education (Yu, 2006).

Entrepreneurial knowledge that the students most want to learn is start-up business management. Technological management, laws and regulations, and finance management rank the second, third and fourth respectively. And students show the slightest interest in marketing and the support policy for entrepreneurship. This findings provide a useful reference to curricular design and the preparation of teaching plans for academic leaders and educational administrators.

According to the survey on the qualities that teachers should possess in entrepreneurship education, students choose the "entrepreneurial experience" and "practical experience” much higher than the other options. It indicates that students need the direct guidance from entrepreneurs, and entrepreneurial practice as much as possible. There for it's important and necessary to promote school-enterprise cooperation for faculty development in entrepreneurship education.

\section{Entrepreneurial Curriculum Design and Differential Demand Analysis}

The survey data show that the demand for entrepreneurship education varies with different grades and professional background. To meet the different needs of students, developing entrepreneurship education properly can not only allocate education resources effectively to improve the efficiency and effect of the entrepreneurship education, but also avoid becoming a mere formality or a sandwich between entrepreneurship education and professional education (Xu, 2008).

Table 2.

The differentiation in curriculum evaluation of entrepreneurship education based on various basic variables.

\begin{tabular}{|c|c|c|c|c|c|c|c|c|c|}
\hline \multirow{2}{*}{ level } & \multirow{2}{*}{ PC\% } & \multicolumn{2}{|c|}{ Gender } & \multicolumn{3}{|c|}{ Major } & \multicolumn{3}{|c|}{ Grade } \\
\hline & & Male & Female & STEM & $\mathrm{E} \& \mathrm{M}$ & A \& H & P \& D & $\mathrm{F} \& \mathrm{~S}$ & $\mathrm{~J} \& \mathrm{~S}$ \\
\hline \multirow{2}{*}{ Significant effect } & Total & $66.2 \%$ & $33.8 \%$ & $39.4 \%$ & $28.2 \%$ & $32.4 \%$ & $46.5 \%$ & $26.8 \%$ & $19.7 \%$ \\
\hline & Variable & $26.7 \%$ & $15.6 \%$ & $23.5 \%$ & $22.5 \%$ & $18.9 \%$ & $39.3 \%$ & $15.6 \%$ & $13.1 \%$ \\
\hline \multirow{2}{*}{ Modest effect } & Total & $54.1 \%$ & $45.9 \%$ & $38.8 \%$ & $25.9 \%$ & $35.3 \%$ & $24.1 \%$ & $31.2 \%$ & $38.8 \%$ \\
\hline & Variable & $52.3 \%$ & $50.6 \%$ & $55.5 \%$ & $49.4 \%$ & $49.2 \%$ & $48.8 \%$ & $43.4 \%$ & $61.7 \%$ \\
\hline \multirow{2}{*}{ Little effect } & Total & $41.6 \%$ & $58.4 \%$ & $28.1 \%$ & $28.1 \%$ & $43.8 \%$ & $11.2 \%$ & $56.2 \%$ & $30.3 \%$ \\
\hline & Variable & $21.0 \%$ & $33.8 \%$ & $21.7 \%$ & $21.8 \%$ & $32.0 \%$ & $11.9 \%$ & $41.0 \%$ & $25.2 \%$ \\
\hline
\end{tabular}

Note: data in italics indicates that this factor (curriculum effect) exists significant differences $(p<0.05)$ in the corresponding categories. E \& M denotes economics and management majors, A \& H denotes arts and humanities majors, P \& D denotes postgraduates and doctoral candidates, F \& S denotes freshmen and sophomores, J \& S denotes junior and senior college students.

Table 3.

Rank of demand for entrepreneurial curriculum.

\begin{tabular}{llcl}
\hline Rank & Effective entrepreneurial curriculum & Entrepreneurial knowledge most interested & Qualities teachers should possess \\
\hline First & Entrepreneurship internship & Start-up business management & Technological management \\
Second & Entrepreneurial management course & Laws and regulations \\
Third & $\begin{array}{l}\text { Entrepreneurial course which involved } \\
\text { in professional curriculum } \\
\text { Fourth }\end{array}$ & Short-term internship & Finance management experience \\
\hline
\end{tabular}




\section{Differential Demand for Entrepreneurial Curriculum in Different Grades}

There are significant differential needs of undergraduates, postgraduates and doctoral candidates for entrepreneurial curriculum. The undergraduates show great interest in entrepreneurial internship courses, while the postgraduates and doctoral candidates pay more attention to entrepreneurial management courses that related to their majors and research directions. Most of postgraduates and doctoral candidates have work or internship experience, or have ever participated in their professor's research project, so they need to involve entrepreneurship education in professional learning and practice, and integrate entrepreneurship education with their professional and research directions.

\section{Differential Demand for Entrepreneurial Curriculum in Different Majors}

The students of different majors show interest in different entrepreneurial courses. According to the survey data, the students in economics, management, arts and humanities majors put stress on learning professional entrepreneurial management, attending entrepreneurship internship in business entities, and wish to integrate entrepreneurship education with their professional courses. On the other hand, the students in STEM majors think that it's difficult to integrate entrepreneurial knowledge with their expertise, and choose to acquire entrepreneurial knowledge in public elective courses, graduate internship programs, and short-term internship courses.

There are four reasons for the results:

Firstly, the students in STEM majors are restricted by the total course credits (hours), so the professional courses account for most of time that teachers can just instruct professional theories in class.

Secondly, STEM education is short of professional teachers and weak in transforming the professional knowledge to scientific and technological achievements.

Thirdly, to some extent, the results reflect the low efficiency and effectiveness of the teaching plan in practical links.

Lastly, the curriculum system in economics and management majors has included the knowledge of marketing and business operations, so the students desire to attend entrepreneurship internship and entrepreneurial management courses directly.

\section{Entrepreneurial Preparation and Perceptions}

\section{Survey on Entrepreneurial Preparation and Perceptions}

In order to further understand the students' entrepreneurial values and demand for entrepreneurial support, this study investigates the following questions, such as the source of entrepreneurial motivation, the most difficult problems and the most desirable assistance in establishing a business. The survey results are shown in Table 4.

As the results shown, more than half of the students believe that the most appropriate entrepreneurial opportunity is a period after work, the option of starting a business before graduation ranks the second, but only $4.9 \%$ of students choose to drop out of college to establish a business.

The survey on the entrepreneurial motivation aims to study the entrepreneurial values of the college students. The data show that more than half of the students to choose to realize individual ideal and create personal wealth as the main motivetion, while the employment pressure only ranks the fourth. This indicates that the students' incentive to start a business is to realize or add self-value, reflects the positive entrepreneurial values of contemporary college students, and proves that the type of entrepreneurial activity of young people has turned to the "challenging” entrepreneurship (Davey et al., 2011).

Lack of funds and ideal entrepreneurial projects rank the top two for the most difficult problems in establishing a business, and lack of guidance and legal knowledge rank thereafter. This indicates that lack of entrepreneurial start-up funds and ideal entrepreneurial projects are the most difficulties that the college students encountered in the early days of starting their new business.

Start-up funds, entrepreneurial knowledge and skills training rank the top two for the most desirable assistance entrepreneurrial practice. The results coincide with the rank of the most difficult problems. It shows that college students eager to get financial support for start-up, as well as more comprehensive and professional entrepreneurship education and skills training.

\section{Differential Analysis}

The students with various personal characteristics differ in entrepreneurial plan. According to the survey data, of the students who have entrepreneurial intention, males are more than females, students in STEM, arts and humanities majors are more than in economics and management majors, postgraduates and doctoral candidates are significantly more than undergraduates. With regard to the origin of students who have entrepreneurial intention, the students from the Midwest are significantly more than from the east, and 55.3\% from the middle and $53 \%$ from the western have entrepreneurial intention respectively. Meanwhile, $56.0 \%$ from the village and township have entrepreneurial intention, significantly more than $36.0 \%$ from the provincial capitals and municipalities. Detailed statistical data are shown in Table 5.

Table 4.

Results of survey on entrepreneurial preparation and perceptions.

\begin{tabular}{|c|c|c|c|}
\hline Entrepreneurial opportunity & Entrepreneurial motivation & Difficult problems rank & Desirable assistance ranks \\
\hline Start a business after work (64.7\%) & Realize individual ideal (32.3\%) & Lack of funds & Entrepreneurial funds \\
\hline Start a business before graduation (18.9\%) & Create personal wealth (24\%) & Lack of the ideal projects & $\begin{array}{l}\text { Entrepreneurial knowledge } \\
\text { and skills training }\end{array}$ \\
\hline Start a business while graduating (11.5\%) & $\begin{array}{l}\text { Encouraged by successful business } \\
\text { personage }(13.2 \%)\end{array}$ & Lack of marketing skills & Entrepreneurial guidance \\
\hline $\begin{array}{l}\text { Drop out of college to establish } \\
\text { a business }(4.9 \%)\end{array}$ & Employment pressure (12.1\%) & Lack of courage to bear responsibility & Entrepreneurship internship \\
\hline
\end{tabular}


Table 5.

Different entrepreneurial plan of students with various characteristics.

\begin{tabular}{|c|c|c|c|c|c|c|c|}
\hline \multirow{2}{*}{ Option } & \multirow{2}{*}{ PC\% } & \multicolumn{3}{|c|}{ Major } & \multicolumn{3}{|c|}{ Grade } \\
\hline & & STEM & $\mathrm{E} \& \mathrm{M}$ & A \& H & $P \& D$ & $F \& S$ & $J \& S$ \\
\hline \multirow{2}{*}{ With intention } & Total & $35.7 \%$ & $25.4 \%$ & $38.8 \%$ & $26.5 \%$ & $35.7 \%$ & $29.2 \%$ \\
\hline & Variable & $51.0 \%$ & $36.3 \%$ & $50.2 \%$ & $49.0 \%$ & $48.4 \%$ & $37.0 \%$ \\
\hline \multirow{2}{*}{ No intention } & Total & $26.4 \%$ & $41.5 \%$ & $32.1 \%$ & $23.1 \%$ & $26.9 \%$ & $48.6 \%$ \\
\hline & Variable & $27.5 \%$ & $43.1 \%$ & $30.2 \%$ & $31.2 \%$ & $26.5 \%$ & $44.8 \%$ \\
\hline \multirow{2}{*}{ Never think about it } & Total & $33.8 \%$ & $32.3 \%$ & $33.8 \%$ & $23.8 \%$ & $41.5 \%$ & $32.3 \%$ \\
\hline & Variable & $21.6 \%$ & $20.6 \%$ & $19.6 \%$ & $19.7 \%$ & $25.1 \%$ & $18.3 \%$ \\
\hline
\end{tabular}

Note: E \& M represents economics and management majors, A \& H denotes arts and humanities majors, P \& D denotes postgraduates and doctoral candidates, F \& S denotes freshmen and sophomores, J \& S denotes junior and senior college students.

Besides, the survey shows that the entrepreneurial enthuseasm of freshmen and sophomores are significantly greater than the junior and senior students, namely students in lower grades have greater entrepreneurial enthusiasm than who in higher grades. This indicates that the students become much more rational at the choice of future career and entrepreneurship with age.

\section{Recommendations for the Entrepreneurship Education in Colleges and Universities}

\section{Attach Importance to the "Principals" Projects}

The attitude of university presidents has a great impact on the effect of entrepreneurship education. Only the top policymaker in the colleges and universities attach importance to the entrepreneurship education, the following key issues can be solved:

- Whether to involve entrepreneurship education into the school's educational plan.

- Whether to involve entrepreneurship education into the overall teaching system.

- Whether to establish entrepreneurship education institutions of self-management.

Entrepreneurship education is a strategic and systematic project that can't just be a formality and in a hurry to succeed. The essence of entrepreneurship education is quality-oriented education and innovative education, so the task of entrepreneurship education is to create good cultural atmosphere which can encourage the initiatives and innovative spirit of the educational administrators and professional teachers (Kirby \& Ibrahim, 2010; Lee et al., 2005).

\section{Innovate the Curriculum System of Entrepreneurship Education}

The survey shows that the demands of students with various characteristics are different. To meet with these diverse needs, colleges and universities should offer different levels of entrepreneurial courses for different objects, and integrate them into professional courses. The curricular design should not be "one size fits all", and enforced as "required courses". To some extent, this way is not only contrary to the original intention of entrepreneurship education, but also against the laws of scientific education.

The curriculum system of entrepreneurship education should break the shackles of the framework of the existing professional education (Mao, 2009), such as innovating the mentality, establishing a substitute cross-discipline and cross-specialty course or credit platform, making full use of the existing teaching practice and identifying the equivalent extracurricular activities and technological achievements. These methods provide some innovative ways of curricular management to realize the "soft-landing" of entrepreneurship education which address two key issues:

- The proper curricular design.

- “Equivalent” evaluation of students' innovative and entrepreneurial abilities.

\section{Strengthen and Emphasize the Faculty Development of Entrepreneurship Education}

Lack of skilled professional teachers is one of the key issues in entrepreneurship education. In the practice of entrepreneurship education, a stable faculty is urgently needed. Currently the university teachers who have entrepreneurial experience and are familiar with the students, the development of industry and the demand trends of new products, are valuable resources for entrepreneurship education. Therefore it's an important task to develop these potential professionals.

The double-tutors system involving schools' and enterprises' is an effective resource to develop teachers out of campus and also more suitable for the higher grades of the undergraduate stage. Off-campus tutors are valuable resources for entrepreneurship education, especially welcomed by students in practical activities. And this model addresses three key issues:

- Attracting the qualified entrepreneurship teachers in colleges and universities.

- Training the professional entrepreneurship teachers.

- Developing off-campus entrepreneurship faculty.

\section{Make Full Use of Social Resources to Develop Entrepreneurship Education}

Developing entrepreneurship education is not only the responsibility of the colleges and universities, but also of the whole society. Universities should make full use of all kinds of social resources to develop a system that colleges and universities are the main part and encourage positive interaction among the four elements of governments, schools, enterprises and society. The joint platform promotes the implementation of the entrepreneurship education effectively which can provide comprehensive support, such as policy support, school support, 
corporate funds and social practice for college students to start their own business.

The government puts forth various policies to encourage students to start business and widely publicize these policies. The colleges and universities enhance cooperation with enterprises to build internship platforms for students. The communities establish Students' Start-up House for entrepreneurial guidance. All of these should be the important chains of entrepreneurship education

\section{Acknowledgements}

This research was financially supported by the China Shanghai Municipal Research Project of Education and Science 2011 (B11041), the Leading Academic Discipline Project of Shanghai Education Committee, China (2016[67]) and the Liberal Arts and Social Science Training Program in University of Shanghai for Science and Technology by a grant from Shanghai Academic Degrees Committee (2012[13]).

\section{REFERENCES}

Davey, T., Plewa, C., \& Struwig, M. (2011). Entrepreneurship percep- tions and career intentions of international students, Education \& Training, 53, 335-352. doi:10.1108/00400911111147677

Kirby, D. A., \& Ibrahim, N. (2010). Entrepreneurship education and the creation of an enterprise culture: Provisional results from an experiment in Egypt. Internatinal Entrepreneurship and Management, 7, 181-193. doi:10.1007/s11365-010-0153-0

Lee, S. M., Chang, D. S., \& Lim, S. B. (2005). Impact of entrepreneurship education: A comparative study of the US and Korea. International Entrepreneurship and Management, 1, 27-43. doi:10.1007/s11365-005-6674-2

Mao, C. Y. (2009). The study of $2+1+1+\mathrm{X}$ training model for multi-level entrepreneurial talent in colleges and universities. Technoeconomics \& Management Research, 5, 119-122. http://www.cqvip.com/qk/95695x/200905/31331302.html

Postigo, S., \& Tamborini, M. (2005). Entrepreneurship education in Argentina: The case of the San Andres University. Business Education and Emerging Market Economies, 2, 267-282. doi:10.1007/1-4020-8072-9_17

$\mathrm{Xu}$, J. (2008). Entrepreneurship education mode in higher education tnstitutions-Based on case study, Educational Research, 4, 99-102. http://www.cqvip.com/main/none.aspx?lngid=27026983

$\mathrm{Yu}$, R. L. (2006). An empirical study on undergraduate enterprise education-Taking Xiamen University as a case (pp. 39-51). Xiamen: Xiamen University.

http://cdmd.cnki.com.cn/Article/CDMD-10384-2007055641.htm 